\title{
II
}

\section{O PAPEL DO LEITOR NO HORROR LOVECRAFTIANO: EXTRAPOLAÇÃO E SUBVERSÃO EM "THE INNSMOUTH HERITAGE" (1992) DE BRIAN STABLEFORD}

Daniel Iturvides Dutra (UFRGS)

Recebido em 26 fev 2017. Daniel Iturvides Dutra é graduado em Letras/ Aprovadoem 20 abr 2017. Licenciatura Plena em Língua Inglesa e Respectiva Literatura pela Universidade Católica de Pelotas. Possui Especialização em Literatura Comparada pela Universidade Federal de Pelotas, Mestrado em Literatura Comparada pela Universidade Federal do Rio Grande do Sul e Doutorado em Literatura Comparada pela Universidade Federal do Rio Grande do Sul.

Resumo: O presente artigo visa analisar o universo literário de H.P. Lovecraft, conhecido como Mitos Chtulhu, sob a perspectiva do papel do leitor na produção de sentido do texto. Analisaremos, num primeiro momento, a releitura que Brian Stableford fez, em seu conto "The Innsmouth Heritage" (1992), da obra de H.P. Lovecraft. Num segundo momento discutiremos o papel do leitor, e como o conhecimento deste acerca dos Mitos Cthulhu, mais especificamente sobre a novela "A Sombra em Innsmouth" (1936) de H.P. Lovecraft, influencia a interpretação de "The Innsmouth Heritage" (1992). Para tanto utilizaremos a teoria do leitor-modelo de Umberto Eco, combinada com o trabalho de Tzevan Todorov sobre o "estranho" e "o fantástico", para demonstrar que "The Innsmouth 
Heritage" pode ser lido tanto como um texto fantástico ou estranho, dependendo do quanto o leitor está familiarizado com a obra de H.P. Lovecraft. Palavras-chave: Lovecraft; Horror; Cthulhu mitos.

Abstract: This article aims to analyze the literary universe of H. P. Lovecraft, known as Cthulhu Mythos, throught the reader's role in the text. We will look at first at the reimagining of H. P. Lovecraft's work by Brian Stableford in his short story "The Innsmouth Heritage" (1992). Secondly, we will discuss the role of the reader, and how his knowledge about the Cthulhu Mythos, more specifically on the novel "The Shadow over Innsmouth" (1936) by H.P. Lovecraft, influences the interpretation of "The Innsmouth Heritage" (1992). For this purpose we will use Umberto Eco's theory of the Model Reader, combined with the writings of Tzevan Todorov on the "uncanny" and the "fantastic", to demonstrate that "The Innsmouth Heritage" can be read either as one or another, depending on the reader's familiarity with the writings of HP Lovecraft.

Keywords: Lovecraft; Horror; Cthulhu mythos.

\section{INTRODUÇÃO}

O escritor H.P. Lovecraft, ao deixar seu legado literário, o deixou de uma forma que permitisse que outros autores explorassem os seus mundos ficcionais. A gênese desse fenômeno está na correspondência que mantinha com autores como Robert E. Howard, Clark Ashton Smith, Frank Belknap Long, August Derleth, Robert Bloch, entre outros. Lovecraft, nas suas cartas, os incentivava a acrescentar as criações de sua mitologia ficcional como o grimório Necronomicon e entidades como Cthulhu - em suas histórias, enquanto fazia o mesmo, citando criações de seus colegas em sua literatura, como, por exemplo, ao mencionar a 
entidade Tsathoggua, de Clark Ashton Smith, em seu conto "Um Sussurro na Escuridão" (1931).

O que era apenas um jogo de referências entre amigos escritores ganhou proporções maiores à medida que, após a morte de Lovecraft, outros autores começaram a tomar suas criações de empréstimo e a expandir o seu universo. Não tardou para que as editoras percebessem o nicho de mercado e começassem a publicar antologias com histórias de outros autores situadas no universo de Lovecraft. A este universo convencionou-se chamar de Mitos Cthulhu, termo cunhado pelo amigo de Lovecraft e também escritor August Derleth, responsável pela fundação da Arkham House, editora que publicou não apenas os trabalhos de Lovecraft após sua morte, mas também pelas primeiras antologias de autores interessados em explorar o seu legado literário. Dessa forma, consolidou-se o subgênero de horror que ficou conhecido como horror lovecraftiano.

Sobre o uso das criações de Lovecraft por outros autores, Guilherme da Silva Braga comenta:

No entanto, Lovecraft jamais tentou sistematizar o universo em torno da mitologia que criou, ou sequer estabelecer uma coerência interna entre as descrições e os atributos das entidades que aparecem nas próprias obras, o que oferece uma ampla margem de licença artística para as centenas de autores que se aventuram a fazer contribuições para o ciclo mítico a que deu origem. Esse foi sem dúvida um grande trunfo para a permanência da obra legada pelo demiurgo de Providence [...]. (BRAGA, 2014, p.13)

Em outras palavras, a palavra "mitos" em Mitos Cthulhu deve ser encarada com ressalvas, visto que nunca foi a intenção de 
Lovecraft criar uma mitologia, e é importante também ressaltar que o termo Mitos Cthulhu foi cunhado depois de sua morte. Em suma, quando se fala em Mitos Cthulhu, deve-se considerá-lo mais como um cenário geral criado por Lovecraft, onde sua maleabilidade permite a outros autores introduzirem seus acréscimos, do que uma estrutura mitológica propriamente dita.

Sendo assim, primeiramente investigaremos como outros autores lançaram mão da licença artística na construção de suas próprias narrativas lovecraftianas e, em seguida, qual o papel do leitor nesse processo. O objeto de análise será o conto "The Innsmouth Heritage" (1992), de Brian Stableford.

Tencionamos argumentar que o conhecimento do leitor acerca do universo de H.P. Lovecraft exerce um papel fundamental na compreensão de "The Innsmouth Heritage". Demonstraremos que Stableford escreveu sua história, uma espécie de semi-continuação da novela A Sombra em Innsmouth, de Lovecraft, levando em consideração o saber do leitor a respeito desta obra, e como tal conhecimento produz leituras diferentes.

\section{LENDO O HORROR LOVECRAFTIANO}

$\mathrm{Na}$ literatura de H.P. Lovecraft, cujo termo "horror lovecraftiano" costuma ser usado para designar tanto as obras de sua autoria quanto as de terceiros, as histórias tendem a estabelecer relações, e o grau varia de narrativa para narrativa. Em alguns casos há referências a nomes, lugares e eventos que pouco ou em nada influenciam a leitura do texto, enquanto que, em outros, as referências, ou mais especificamente, a capacidade do leitor em identificá-las, alteram todo o sentido do texto. 
Para compreendermos melhor essa questão é necessário analisar a função do gênero literário no processo de leitura e interpretação. Jorge Luiz Borges comenta:

Eu acrescentaria uma observação pessoal: os gêneros literários dependem, talvez, menos dos textos do que do modo como são lidos. A obra estética requer a integração leitor/texto, para só então existir. [...] Há um tipo de leitor atual, o leitor de ficção policial. Esse leitor, que se encontra em todos os países do mundo e que se conta aos milhões, foi criado por Edgar Allan Poe. Suponhamos que não exista esse leitor, ou - talvez algo mais interessante - que se trate de uma pessoa distante de nós. Pode ser um persa, um malaio, um camponês, uma criança, uma pessoa a quem dizem, por exemplo, que Dom Quixote é um conto policial. Imaginemos que esse hipotético personagem tenha lido novelas policiais e comece a ler Dom Quixote. Que lê, então?

'Em certa região da Mancha, cujo nome não quero lembrar, não faz muito tempo vivia um fidalgo...'. E já esse leitor está cheio de suspeitas, porque o leitor de contos policiais é alguém que lê com incredulidade, com desconfiança, uma desconfiança especial.

Por exemplo: se ele lê a frase 'Em certa região da Mancha...', naturalmente imagina que aquilo não aconteceu na Mancha. Depois: '... cujo nome não quero lembrar...'. Por que Cervantes não quis lembrar? Porque, sem dúvida, Cervantes era o assassino, o culpado. Logo vêm o resto: '... não faz muito tempo...' - possivelmente o que vier a acontecer não será tão aterrador quanto o futuro.

A novela policial gera um tipo especial de leitor. 
Costuma-se esquecer isto, ao se julgar a obra de Poe. Porque, se Poe criou o conto policial, criou, mais tarde, o tipo de leitor de ficção policial. (BORGES, 1985, p.31-32)

As assertivas de Borges, mutatis mutandis, explicam a relação entre o horror lovecraftiano enquanto subgênero e o papel de seus leitores. Em outras palavras, tal qual um leitor de contos policiais possui certas expectativas acerca do gênero policial, e estas expectativas foram criadas por Edgar Allan Poe, o leitor de horror lovecraftiano também possui um conjunto de expectativas ao ler uma obra de Lovecraft, ou um texto de outro escritor que se propõe a dar continuidade ao universo do autor. Em suma, o horror lovecraftiano, assim como o conto policial, também possui um tipo de leitor especial: o leitor lovecraftiano.

Pode-se, dessa forma, dividir os leitores de H.P. Lovecraft em dois grupos: o leitor neófito e o leitor iniciado, que será chamado de leitor lovecraftiano.

Para entendermos de uma forma prática como funciona a diferença de leituras entre um leitor neófito e um leitor lovecraftiano, vamos fazer uma breve análise de duas obras do autor, a novela $A$ Sombra em Innsmouth (1931) e o conto "A Coisa na Soleira da Porta" (1933). Na narrativa de A Sombra em Innsmouth, uma raça de seres submarinos conhecida como "Os Abissais" há muito tempo emergiu da superfície para procriar com os habitantes da pequena cidade portuária de Innsmouth - parte de um acordo que prometia riqueza aos habitantes - gerando assim uma raça de seres metade humana e metade anfíbia. A raça híbrida de Innsmouth é imortal e, durante a juventude, possuem uma aparência humana, vivendo normalmente 
na superfície. Porém, à medida que envelhecem, a raça híbrida aos poucos perde seus traços humanos e adquire traços cada vez mais anfíbios, e, por fim, se juntam aos "Os Abissais" no fundo do oceano. O protagonista, que narra em primeira pessoa, descobre a verdade sobre Innsmouth e alerta o governo norte-americano, o que culmina num ataque destrutivo a cidade por parte da Marinha dos Estados Unidos.

Já em "A Coisa na Soleira da Porta" o narrador em primeira pessoa, Daniel Upton, relata o fatídico destino de seu amigo Edward Pickman Derby, e como as circunstâncias o levaram a matar seu amigo com seis tiros de revólver. Derby se casara com Asenath Waite, e, após alguns anos, Upton começa a notar bizarras mudanças de comportamento em seu amigo. Derby procura Upton, e conta que o falecido pai de sua esposa, Ephraim Waite, conhecido em Arkham - cidade onde se passa boa parte do conto - por ter estranhas habilidades sobrenaturais, não estava de fato morto e havia de alguma forma possuído o corpo de sua esposa Asenath, e agora tencionava possuir também o corpo de Derby.

O narrador Upton fala sobre Innsmouth, Asenath e Ephraim Waite:

Edward estava com trinta e oito anos quando conheceu Asenath Waite. Ela devia ter perto de vinte e três, na época, e estava seguindo um curso especial de metafísica medieval na Miskatonic. A filha de um amigo meu a conhecia de antes - da Escola Hail, de Kingsport - e tratara de evitá-la devido à sua estranha reputação. Era trigueira, apequenada e de muito boa aparência, exceto pelos olhos muito saltados, mas alguma coisa em sua expressão afastava as pessoas mais sensíveis. Entretanto, era sobretudo sua origem e sua 
conversa que faziam as pessoas comuns a evitar. Descendia dos Waite de Innsmouth, e muitas lendas obscuras se acumularam, durante gerações, sobre a decrépita e quase deserta Innsmouth e sua gente. Correm histórias sobre pactos pavarosos por volta de 1850, e sobre um elemento estranho, 'não inteiramente humano', nas antigas famílias do arruinado porto pesqueiro - histórias que só ianques dos velhos tempos conseguem inventar e repetir com a devida 'horripilência'. (LOVECRAFT, 2007, p.163-164)

Na passagem abaixo o narrador compartilha o quanto sabe a respeito de Innsmouth ao comentar sobre seu amigo Derby.

Sim, agora ele entendia o sangue de Innsmouth. Tinha havido uma conspiração com criaturas marinhas - era horrível... E o velho Ephraim - ele havia conhecido o segredo, e quando ficou velho fez uma coisa abominável para se manter vivo... ele pretendia viver para sempre... Asenath conseguiria - uma demonstração bem sucedida já havia ocorrido. (LOVECRAFT, 2007, p.173-174)

Portanto, como é a percepção de um leitor neófito e um leitor lovecraftiano de "A Coisa na Soleira da Porta"? Vamos trabalhar com a suposição de que alguém que nunca tenha lido Lovecraft decida ler o conto "A Coisa na Soleira da Porta". Para este leitor palavras como "Innsmouth", "Necronomicon", "Arkham", "Universidade Miskatonic" não terão o mesmo significado que tem para o leitor que conhece textos como "O Chamado de Cthulhu" (1928), "O Horror de Dunwich" (1929) e A Sombra em Innsmouth (1936), onde tais nomes têm um papel mais preponderante na narrativa e seus significados são mais bem esclarecidos. Poder-se-ia muito bem mudar ou omitir os nomes, aqui já citados, do conto "A Coisa 
na Soleira da Porta" que em nada alteraria a percepção do leitor neófito, visto que é a primeira vez que ele entra em contato com esses. Essa diferença de significados das palavras entre o leitor lovecraftiano e o leitor neófito é chamado de interiorização da palavra. Paulo Rogério Stella explica:

A compreensão do mundo, pelo sujeito, acontece no confronto entre as palavras da consciência e as palavras circulantes na realidade, entre o interno e o externamente ideológico. A interiorização da palavra acontece como uma palavra nova, surgida da interpretação desse confronto. (STELLA, 2005, p.179)

O autor explica como funciona a interiorização da palavra usando o seguinte exemplo: o de um estudante que aprende o significado da palavra "passear". Na escola ele vai aprender que "passear" significa se mover de um ponto físico para outro com o objetivo de entretenimento. Porém, Stella utiliza a seguinte ilustração para demonstrar que uma palavra pode ter outros significados atrelados a ela:

Esse mesmo estudante, adolescente, residindo em uma cidade grande, violenta e sem muitas opções de diversão, tem no shopping Center um local de encontro dos amigos. Por isso, utiliza a palavra 'passear' na sua vida cotidiana atrelada à saída ao shopping center ou ao cinema. Imaginemos agora que o estudante seja visto fazendo uma pesquisa na internet e um colega lhe pergunta: ' $O$ que vai fazer mais tarde?' A isso o estudante responde: 'Acho que vou passear no shopping'. E o colega continua: 'falando em passear, você já passeou pelos sites de compras? É muito divertido'. (STELLA, 2005, p.180) 
Dito de outra forma, tal sentido dado à palavra "passear" no exemplo - o signo tem seu significado atrelado ao ato de frequentar um shopping center ou visitar sites de internet - inexiste na mente de alguém que vive em uma cidade pequena que não possui um shopping center e não tem acesso a internet. O estudante no exemplo de Stella seria alguém que, ao morar em um grande centro urbano, interiorizou outros sentidos para a palavra "passear", além daquele aprendido na escola ou em dicionários, que seria o significado que até então circula no repertório do indivíduo.

O processo de interiorização se dá no embate entre o signo internamente circulante e o externo. Ele acontece na compreensão dessas nuances de tons, circulantes no signo externo. [...] O resultado do confronto entre os significados conhecidos pela consciência e o sentido construído no intuito comunicativo do locutor leva um novo ponto de vista sobre o signo, instaurado na consciência. (STELLA, 2005, p.187)

De forma análoga funciona a leitura de um conto de Lovecraft por parte de um leitor neófito. As palavras "Innsmouth", "Necronomicon", "Arkham" e outras são tão distantes do seu arcabouço de conhecimento pessoal quanto à expressão "passear em sites de compras" o é para alguém que viveu a vida inteira numa região sem acesso a internet. Porém, quando um leitor lovecraftiano lê "A Coisa na Soleira da Porta", e encontra as palavras Innsmouth e Necronomicon citadas - além de insinuações sobre a aparência de Asenath Waite que remetem a novela "A Sombra em Innsmouth" logo as associa a outros contos do autor, e conhece o significado e história por trás desses nomes, e por esta razão este leitor interpreta "A Coisa na Soleira da Porta" de uma forma diferente do leitor neófito. 
No entanto, no momento em que o leitor neófito toma contato com outros textos de Lovecraft, toda sua percepção sobre a obra do autor muda. Ou seja, não apenas as palavras "Innsmouth", "Necronomicon", entre outras passam a ter um significado diferente, mas também os eventos narrados em "A Coisa na Soleira da Porta" adquirem um novo sentido. O conto passa a ser visto não como um evento isolado, e sim como parte de uma série de acontecimentos bizarros da região da Nova Inglaterra dos contos de H.P. Lovecraft que mistura cidades fictícias como Arkham, Innsmouth e Kingsport com locais reais - e envolvem tanto uma série de raças antigas vindas das profundezas dos oceanos ou do espaço quanto grimórios de segredos ocultos.

Sendo assim, todo um leque de novas implicações surge na mente do leitor neófito em Lovecraft, da mesma forma que a palavra "passear" adquire novas implicações quando alguém que passou a vida inteira numa cidade pequena sem internet se muda para uma cidade grande, ou seja, a palavra "passear" passa a ser associada a shopping centers e sites de compras. Este é o fenômeno de interiorização da palavra, que, enquanto signo, tem seu novo significado acrescentado ao repertório do indivíduo.

\section{O LEITOR-MODELO DE UMBERTO ECO E O FANTÁSTICO DE TZVETAN TODOROV}

Em seu Introdução à Literatura Fantástica (1975), Todorov se propõe a estabelecer uma tipologia da literatura que lida com temas que extrapolam explicações racionais, a saber, o fantástico.

Chegamos assim ao coração do fantástico. Em um mundo que é o nosso, que conhecemos, 
sem diabos, sílfides, nem vampiros se produz um acontecimento impossível de explicar pelas leis desse mesmo mundo familiar. Que percebe o acontecimento deve optar por uma das duas soluções possíveis: ou se trata de uma ilusão dos sentidos, de um produto de imaginação, e as leis do mundo seguem sendo o que são, ou o acontecimento se produziu realmente, é parte integrante da realidade, e então esta realidade está regida por leis que desconhecemos. Ou o diabo é uma ilusão, um ser imaginário, ou existe realmente, como outros seres, com a diferença de que rara vez o encontra. (TODOROV, 1975, p.30)

O cerne da tese de Todorov se sustenta no seguinte ponto: é a reação do personagem diante dos eventos, e o leitor compartilhar de sua reação, o que determina o sentido do texto.

Se as leis da realidade permanecem intactas e permitem explicar os fenômenos descritos, dizemos que a obra se liga a um outro gênero: o estranho. Se, ao contrário, decide que se devem admitir novas leis da natureza, pelas quais o fenômeno pode ser explicado, entramos no gênero maravilhoso. (TODOROV, 1975, p.48)

Portanto, o autor argumenta que a literatura fantástica pode ser dividida em cinco subcategorias: o fantástico puro, o fantástico estranho, o fantástico maravilhoso, o estranho puro e o maravilhoso puro. Desta tipologia é do nosso interesse apenas o fantástico maravilhoso e o estranho puro. Segundo Todorov, numa história de fantástico maravilhoso o personagem, a princípio, hesita em aceitar o fantástico, para num momento posterior da narrativa aceitá-lo. Por sua vez, o estranho puro seriam histórias onde acontecimentos sobrenaturais são, no final, 
explicados de forma racional, mas que, mesmo assim, não deixam de surpreender devido a sua natureza inusitada.

A novela A Sombra em Innsmouth e o conto "A Coisa na Porta da Soleira" se encaixam na definição de fantástico maravilhoso de Todorov. Em ambos os textos temos um protagonista que, a princípio, hesita em aceitar a presença do fantástico. No primeiro caso o narrador, ao visitar a cidade de Innsmouth e tomar conhecimento, via os relatos de um velho alcoólatra, das histórias sobre a raça de monstruosos seres anfíbios vivendo no recife próximo a cidade portuária, as ignora como sendo um mero delírio provocado pelo álcool. Porém, mais adiante o protagonista tem um encontro direto com uma das criaturas, comprovando assim a veracidade das histórias que ouvira.

Mesmo procedimento narrativo ocorre em "A Coisa na Soleira da Porta". O narrador Daniel Upton, a princípio cético quanto a história contada pelo seu amigo Edward Pickman Derby sobre sua esposa Asenath Waite ser uma espécie de bruxa que está tentando possuir seu corpo, e atribuir o caso a uma doença mental, não tem escolha senão aceitar a presença do fantástico quando Edward, agora preso no corpo em decomposição da falecida Asenath, aparece na soleira de sua porta.

No entanto, tal classificação entre o estranho puro e o fantástico maravilhoso se torna problemática ao se abordar o conto "The Heritage Innsmouth", de Brian Stableford, pois, embora de uma forma geral o conto possa ser classificado como fantástico maravilhoso, tal percepção vai depender do papel do leitor, a saber, dependerá deste ser um leitor lovecraftiano. Para abordarmos 
melhor esta questão, devemos antes determinar de forma mais exata o que seria o estranho puro.

Todorov explica:

Nas obras pertencentes a esse gênero, relatamse acontecimentos que podem explicar-se perfeitamente pelas leis da razão, mas que são, de uma ou outra maneira, incríveis, extraordinários, chocantes, singulares, inquietantes, insólitos e que, por esta razão, provocam no personagem e no leitor uma reação semelhante a que os textos fantásticos nos voltou familiar. [...] Um conto do Edgar Poe, A queda da casa Usher ilustra o estranho próximo ao fantástico. O narrador chega uma noite à casa, chamado por seu amigo Roderick Usher quem Ihe pede que o acompanhe durante um certo tempo. Roderick é um ser hipersensível, nervoso, que adora a sua irmã, nesse momento gravemente doente. Esta morre uns dias depois, e os dois amigos, em lugar de enterrá-la, colocam o corpo em um dos porões da casa. Transcorrem alguns dias; durante uma noite de tormenta, enquanto os dois homens se encontram em uma habitação em que o narrador lê em alta voz uma antiga história de cavalaria, os sons descritos na crônica parecem ser o eco dos ruídos que se ouvem na casa. Por fim, Roderick Usher fica de pé, e diz, com voz baixa: 'Enterramola viva!' (N.H.E., pág. 105). E em efeito, a porta se abre, e a irmã aparece na soleira. Roderick e sua irmã se abraçam e caem mortos. $O$ narrador foge da casa, bem a tempo para vê-la desmoronar-se no lago vizinho. $O$ estranho tem aqui duas fontes. A primeira está constituída por coincidências (tantas como em uma história em que intervém o sobrenatural explicado). A ressurreição da irmã e a queda da casa depois da morte de seus habitantes poderia parecer sobrenatural; mas Poe não deixa 
de explicar racionalmente ambas as circunstâncias. A respeito da casa escreve o seguinte: ' $O$ olho de um observador minucioso tivesse descoberto talvez uma fissura apenas perceptível que, partindo do teto da fachada se abria um caminho em ziguezague através da parede e ia perder se nas funestas águas do lago' (p.90). E a respeito de lady Madeline: 'Crise freqüentes, embora passageiras, era o singular diagnóstico' (p.94). Por conseguinte, a explicação sobrenatural só está sugerida e não é necessário aceitá-la. [...] A sensação de estranheza parte, pois, dos temas evocados, ligados a tabus mais ou menos antigos. Se admitirmos que a experiência primitiva está constituída pela transgressão, é possível aceitar a teoria de Freud sobre a origem do estranho. Desta maneira, o fantástico resulta, em definitivo, excluído da casa de Usher. (TODOROV, 1975, p.53-54)

Tendo em mente essa definição de Todorov, vamos agora fazer uso de outro conceito para, dessa forma, termos os instrumentos teóricos corretos para a análise. Invocamos a tese de leitormodelo de Umberto Eco. Em Seis Passeios pelos Bosques da Ficção (1986) ele afirma que o autor, ao escrever um texto, o escreve tendo em mente um leitor-modelo. Este seria um leitor ideal que compreenderá o texto exatamente como o autor deseja que este seja compreendido, e que o papel do leitor empírico, ou seja, o leitor comum, é o de tentar se tornar o leitor-modelo que o autor deseja, embora Eco observe que seja muito raro um leitor empírico tornar-se um leitor-modelo por completo.

Para organizar a própria estratégia textual, o autor deve referir-se a uma série de competências (expressão mais vasta do que 'conhecimento de códigos') que confiram conteúdo às expressões 
que usa. Ele deve aceitar que o conjunto de competências a que se refere é o mesmo a que se refere o próprio leitor. Por conseguinte, preverá um Leitor-Modelo capaz de cooperar para a atualização textual como ele, o autor, pensava, e de movimentar-se interpretativamente conforme ele se movimentou gerativamente. Dissemos que o texto postula a cooperação do leitor como condição própria de atualização. Podemos dizer melhor que o texto é um produto cujo destino interpretativo deve fazer parte do próprio mecanismo gerativo. Gerar um texto significa executar uma estratégia de que fazem parte as previsões dos movimentos de outros - como, aliás, em qualquer estratégia (ECO, 1986, p.39).

E conclui:

Os meios são muitos: a escolha de uma língua (que exclui obviamente quem não a fala), a escolha de um tipo de enciclopédia (se começo um texto com |como está claramente explicado na primeira Crítica... I, já reduzi, e bastante corporativamente, a imagem do meu Leitor-Modelo), a escolha de um dado patrimônio lexical e estilístico... Posso fornecer sinais de gênero que selecionam a audiência / Queridas crianças, era uma vez um país distante.../; posso restringir o campo geográfico: / Amigos, romanos, concidadãos!/. Muitos tornam evidente o seu Leitor-Modelo, pressupondo apertis verbis (perdoem-me o oximoro) uma específica competência enciclopédica (ECO, 1986, p.40).

Portanto, estabelecidos os parâmetros teóricos que facilitarão nosso estudo, vamos analisar o conto "The Innsmouth Heritage". 


\section{O PAPEL DO LEITOR EM “THE INNSMOUTH HERITAGE": 0 FANTÁSTICO E O ESTRANHO}

O conto "The Innsmouth Heritage", começa na mesma época em que foi escrito, a saber, no início dos anos 1990. O protagonista é um bioquímico britânico da Universidade de Manchester chamado David Stevenson, que viaja da Inglaterra para Innsmouth após ler um livro escrito por Ann Elliot, uma historiadora e ex-colega de Stevenson em Manchester. O livro de Ann é sobre a cidade de Innsmouth e relata todas as suas histórias bizarras, como o culto macabro da "Ordem Esotérica de Dagon" e as aventuras do capitão Marsh, um marinheiro e proeminente cidadão de Innsmouth, nos mares do pacífico. O livro fala também sobre a deformidade conhecida como "aparência de Innsmouth", termo dado à estranha aparência dos habitantes. Como David é um bioquímico que pesquisa o genoma humano, a "tal aparência" desperta o seu interesse científico.

Ann explica a David que o número de habitantes com a "aparência de Innsmouth", após o ataque da Marinha americana a cidade nos anos 1920, diminuiu drasticamente porque muitos dos nativos casaram-se com pessoas que vieram de fora, restando apenas poucos deformados que vivem reclusos. A pedido de David ela arranja um encontro com o pescador Gideon Sargent, uns dos poucos remanescentes que carregam a deformidade. David explica suas intenções a Sargent:

'We've already begun the business of mapping the human genome,' I told him. 'The job will require the collective efforts of thousands of people in more than a hundred research centers, and even then it 
will take fifteen or twenty years, but we have the tools to do it. While we're doing it, we hope to get closer to the answers to certain basic problems. One of these problems is that we don't know how genes collaborate to produce a particular physical form. We know how they code for the protein building blocks, but we don't know much about the biochemical blueprint that instructs a growing embryo how to develop into a man instead of a whale or an ostrich. Now, this may seem odd, but one of the best ways of figuring out how things work is to study examples which have gone wrong, to see what's missing or distorted. By doing that, you can build up a picture of what's necessary in order for the job to be done properly. For that reason, geneticists are very interested in human mutationsI'm particularly interested in those which cause physical malformation. [...] As soon as I read Ann's book I realized that Innsmouth must have been a real genetic treasure-trove back in the twenties. I hope that there still might be time to recover some vital information'. (STABLEFORD, 2009, p.18)

Sargent consente, após certa insistência de David e Ann, em ceder amostras de DNA para análise, mas não sem antes contar a respeito de seus pesadelos com criaturas monstruosas e reinos submarinos. Pesadelos que Ann, ela própria uma descendente daqueles que possuem "a aparência de Innsmouth", mas que não carrega a deformidade na sua anatomia, também confessa ter. David acaba descobrindo que os pesadelos são comuns nos habitantes da cidade ligados a deformidade. À medida que ganha confiança em David, Sargent convence outros habitantes que possuem a deformidade, reclusos que vivem isolados em suas casas, a ceder amostras de DNA a David que, a pedido de Sargent, 
promete fazer o melhor para descobrir como dar um fim aos pesadelos que o atormentam.

David, assim como a maioria das pessoas, conforme a narrativa infere, não leva a sério as histórias sobre cultos macabros e monstros vivendo no recife próximo a cidade, atribuindo tudo a folclore e ignorância de um povo de uma cidade litorânea do interior. O ataque do governo ao litoral da cidade é explicado como sendo apenas testes da marinha com torpedos, e os incêndios que devastaram boa parte da cidade teriam sido o resultado infeliz do combate policial a contrabandistas de álcool durante a Lei Seca.

A pesquisa de David, como é comum em trabalhos científicos, se estende por vários anos. David e Ann ficam mais íntimos. Sua pesquisa avança e ele aos poucos começa a encontrar respostas para a deformidade. Porém, ao longo desses anos seus objetos de estudo começam a morrer. Gideon Sargent morre em alto-mar num acidente de pesca, e outros deformados morrem de causas naturais ou em acidentes. A princípio, a narrativa adota um tom de natureza fantástica, mas esta natureza é desconstruída por David, que narra a história em primeira pessoa, com explicações racionais. O clímax do conto é seu diálogo com Ann sobre o caso, que ocorre um tempo depois dela ter rejeitado seu pedido de casamento, alegando acreditar nas lendas de Innsmouth, e temendo pelo seu futuro e pelo de David. A rejeição apenas o deixa mais determinado em encontrar respostas lógicas e científicas.

Sobre a "aparência de Innsmouth" David oferece a Ann seguinte explicação:

'You see, the same embryonic structures that produce gills in fish produce different structures in 
other organisms; it's called homology. Conventional thinking, muddied by the fact that we don't really understand the business of blueprinting for physical structure, supposes that when natural selection works to alter a structure into its homologueas when the fins of certain fish were modified by degrees into the legs of amphibians, for instance, or the forelimbs of certain lizards became the wings of birds-the blueprint genes for the new structure replace the blueprint genes for the old. But that's not the only way it could happen. It may be that the new genes arise at different loci from the old ones, and that the old ones are simply switched off. Because they aren't expressed any more in mature organisms they're no longer subject to eliminative natural selection, so they aren't lost, and even though they're bound to be corrupted by the accumulation of random mutations-which similarly aren't subject to elimination by natural selection-they remain within the bodies of descendant species for millions of years. If so, they may sometimes be expressed, if there's a genetic accident of some kind that prevents their being switched off in a particular organism'.

She thought about it for a few moments, and then she said: 'What you're saying is that human beings-and, for that matter, all mammals, reptiles and amphibians-may be carrying around some of the blueprint genes for making fish. These are normally dormant-untroublesome passengers in the body-but under certain circumstances, the switching mechanism fails and they begin to make the body they're in fishy'. 'That's right,' I said. 'And that's what I shall propose as the cause of the Innsmouth syndrome. Sometimes, as with Gideon, it can happen very early in life, even before birth. In other instances it's delayed until maturity, perhaps 
because the incipient mutations are suppressed by the immune system, until the time when ageing sets in and the system begins to weaken'. (STABLEFORD, 2009, p.26)

Ann indaga David sobre os pesadelos, e ele oferece outra explicação racional:

'Where do the dreams fit in?' she asked.

'They don't,' I told her. 'Not into the biology. I never really thought they did. They're a psychological thing. There's no psychotropic protein involved here. What we're talking about is a slight failure of the switching mechanism that determines physical structure. Ann, the nightmares come from the same place as the Esoteric Order of Dagon and Zadok Allen's fantasies-they're a response to fear, anxiety and shame. They're infectious in exactly the same way that rumors are infectious-people hear them, and reproduce them. People who have the look know that the dreams come with it, and knowing it is sufficient to make sure that they do. That's why they can't describe them properly. Even people who don't have the look, but fear that they might develop it, or feel that for some eccentric reason they ought to have it, can give themselves nightmares'. (STABLEFORD, 2009, p.27)

Mesmo após os argumentos de David, Ann ainda assim continua rejeitando a proposta de casamento, não se mostrando totalmente convencida das explicações racionais.

'Ann,' I said, eventually, "you do believe me, don't you? There really isn't a psychotropic element in the Innsmouth syndrome'.

'Yes,' she said. 'I believe you'. 
'Because,' I went on, 'I don't like to see you wasting your life away in a place like this. I don't like to think of you, lonely in selfimposed exile, like those poor lookers who shut themselves away because they couldn't face the world - or who were locked up by mothers and fathers or brothers and sisters or sons and daughters who couldn't understand what was wrong, and whose heads were filled with stories of Obed Marsh's dealings with the devil and the mysteries of Dagon'.

'That's the real nightmare, don't you see - not the horrid dreams and the daft rites conducted in the old Masonic Hall, but all the lives that have been ruined by superstition and terror and shame. Don't be part of that nightmare, Ann; whatever you do, don't give in to that. Gideon Sargent didn't give in - and he told me once, although I didn't quite understand what he meant at the time, that it was up to me to make sure that you wouldn't, either'.

'But they got him in the end, didn't they?' she said. 'The Deep Ones got him in the end'.

'He was killed in an accident at sea,' I told her, sternly. 'You know that. Please don't melodramatize, when you know you don't believe it. You must understand, Ann - the real horrors aren't in your dreams, they're in what you might let your dreams do to you'.

'I know,' she said, softly. 'I do understand'.

I understood too, after a fashion. Her original letter to me had been a cry for help, although neither of us knew it at the time - but in the end, she'd been unable to accept the help that was offered, or trust the scientific interpretation that had been 
found. At the cognitive level, she understood but the dreams, self-inflicted or not, were simply too powerful to be dismissed by knowledge. And that, I thought, was yet another real horror: that the truth, even when discovered and revealed, might not be enough to save us from our vilest superstitions (STABLEFORD, 2009, p.27-28).

Após sair de Innsmouth, com o coração partido ao receber uma nova rejeição de Ann, David descobre, ao tentar entrar em contato meses depois, que ela morreu afogada no litoral da cidade e que, tal qual ocorrera com Gideon Sargent, o seu corpo nunca foi encontrado. O conto encerra com David melancólico, acreditando que tudo não passou de uma série de infelizes coincidências combinadas com ignorância e superstição.

Apresentado este breve resumo de "The Innsmouth Heritage" cabe discutir o conto tendo em vista as teorizações expostas anteriormente, a saber, a diferença estabelecida entre o leitor neófito e o leitor lovecraftiano, os conceitos de fantástico maravilhoso e estranho puro, de Todorov, e o conceito de leitormodelo, de Umberto Eco.

Comecemos com o leitor neófito e o leitor lovecraftiano. Tomemos de empréstimo mais uma vez o exercício imaginativo de Jorge Luis Borges sobre como um leitor de contos policiais que nunca ouviu falar de Miguel de Cervantes leria Dom Quixote, e apliquemos a ideia a "The Innsmouth Heritage". Em outras palavras, como um leitor neófito, a saber, um leitor que nunca leu Lovecraft, e nada sabe a respeito do autor e suas histórias, leria o conto de Brian Stableford.

Para este leitor hipotético as referências que os personagens fazem a eventos passados nada significam. Basicamente o que 
David e Ann discutem em boa parte do conto são as consequências dos eventos de A Sombra em Innsmouth. É importante observar o seguinte aspecto: Ann e David, principalmente o último, sabem tanto quanto o leitor neófito acerca do ocorrido em A Sombra em Innsmouth, ou seja, estão na mais completa ignorância. Tudo que eles sabem são os boatos sobre um culto macabro na cidade, um bombardeio da marinha ao litoral, um incêndio na cidade nos 1920 e pessoas que sofrem de uma estranha deformidade. Quando Ann fala de seus pesadelos, e assustada pergunta a David se ele já viu um Shoggoth, tais termos carecem de sentido para o leitor neófito - que não faz a menor ideia do que seria um Shoggoth e porque aterroriza tanto Ann.

Portanto, o personagem narrador de David Stevenson está na mesma posição do leitor neófito. Ambos desconhecem a verdade sobre Innsmouth e partilham do mesmo ceticismo a respeito das lendas e histórias fantásticas da cidade. Sendo o narrador uma espécie de representante do leitor dentro da história, quando David Stevenson apresenta suas explicações racionais para os eventos aparentemente fantásticos, o leitor neófito é levado a acreditar nas suas conclusões. Afinal, no recorrer da história nenhum evento fantástico em si acontece. Nem o protagonista e nenhum outro personagem tem um encontro com seres extraordinários, ao contrário do narrador de A Sombra em Innsmouth, o que colocaria a narrativa no âmbito do fantástico maravilhoso. David apenas tem contato com histórias de terceiros, que por sua vez as ouviram de outros, e eles próprios nunca presenciaram nada de anormal ou inexplicável, e David consegue fornecer explicações plausíveis, e dentro do âmbito da ciência, para todas as histórias aparentemente fantásticas. 
Porém, a explicação racional de David é surpreendente devido a sua natureza incomum, a saber, os habitantes de uma pequena cidade litorânea sofrem de um distúrbio genético raro que lhes dá uma aparência anfíbia e, como resultado da deformidade, eles desenvolvem uma psicopatologia coletiva para lidar com a angústia de sua condição. A sua explicação é surpreendente, mas, ainda assim, racional e científica. É essa característica de "a realidade é mais estranha do que a ficção", para fazer uso de uma expressão popular, que define o estranho puro. Nenhuma das hipóteses que David apresenta desafia as leis da natureza e da ciência como a conhecemos, mas seu caráter inusitado não deixa de nos surpreender, nesse sentido aproximando o conto do estranho puro.

Sendo assim, "The Innsmouth Heritage", para nosso hipotético leitor neófito, é lido como uma narrativa de estranho puro pelos motivos apontados. No entanto, o conto adquire adornos diferentes quando lido pelos olhos de um leitor lovecraftiano. A começar pelo próprio título, a mera menção a Innsmouth remete o leitor à novela A Sombra em Innsmouth. Por sua vez, quando David e Ann discutem as lendas, os bombardeios da marinha, a "aparência de Innsmouth" e os incêndios na cidade, o leitor está numa posição privilegiada em relação às personagens. Ele sabe que o narrador de "A Sombra em Innsmouth" foi bem-sucedido em convencer as autoridades da veracidade de sua história. Sabe que os ataques de submarinos ao litoral foram uma tentativa de matar "Os Abissais", sabe que o incêndio que tomou conta da cidade provavelmente foi outra ação governamental visando eliminar Innsmouth do mapa, e, pelo diálogo do casal, deduz também que houve toda uma operação do governo para acobertar a verdade. 
Ademais, ele sabe o que é um Shoggoth, conhece todas as suas implicações e o quão terrível e perigosa a criatura é, porque ele leu Nas Montanhas da Loucura (1936) de Lovecraft e está a par de todas as provações que o protagonista desta história, o geólogo William Dyer, sofreu na Antártida.

Acima de tudo, o leitor lovecraftiano sabe o que acontecerá com aqueles que possuem a "aparência de Innsmouth", a saber, com o passar do tempo se transformarão em monstruosidades anfíbias, e migrarão para as profundezas do oceano, e também sabe que os pesadelos são, na verdade, uma espécie de chamado dos "Os Abissais".

Em suma, o leitor lovecraftiano já sabe o que esperar de "The Innsmouth Heritage". Por mais que David se esforce em encontrar explicações racionais, e de fato as encontra, este leitor sabe que David está errado. Portanto, para o leitor lovecraftiano o conto é, pela classificação de Todorov, uma narrativa de fantástico maravilhoso. Na verdade, o conto de Stableford já é para este leitor uma narrativa de fantástico maravilhoso antes mesmo de lê-la, pois o leitor lovecraftiano já sabe de antemão que está entrando numa história onde o fantástico é um fato.

A questão, se observada pela ótica de Umberto Eco, pode ser colocada da seguinte forma: o leitor lovecraftiano seria, em última análise, o leitor-modelo de Brian Stableford. Em outras palavras, Stableford escreveu "The Innsmouth Heritage" com um tipo específico de leitor em mente, o leitor iniciado no universo literário de Lovecraft, e organiza o texto com informações implícitas que apenas esse leitor-modelo conseguiria decifrar. Porém, o aspecto 
que chama a atenção, é o motivo pelo qual o conto de Stabelford foi escolhido para análise, é o modo como a interpretação dos acontecimentos da narrativa diverge drasticamente quando vista pelos olhos do leitor neófito, adquirindo características que a fazem praticamente mudar de gênero, a saber, indo do fantástico maravilhoso ao estranho puro.

O grande mérito do conto de Stableford foi subverter as expectativas do leitor, seja este um neófito ou um leitor lovecraftiano. Enquanto o leitor neófito é levado num primeiro momento a considerar a presença do fantástico para, em seguida, ter essa suspeita destruída pelas explicações de David, e termina aceitando tudo como apenas uma série de bizarras coincidências e eventos estranhos, mas explicáveis pela ciência, ou seja, o estranho puro de Todorov. O leitor lovecraftiano tem suas expectativas subvertidas porque ele espera encontrar as monstruosidades típicas das histórias de Lovecraft, e de outros autores que se apropriaram de seus Mitos Chulhu, como Robert Bloch, Frank Belknap Long, dentre outros, mas não as encontra.

Este desfecho de Stableford, a primeira vista, aparenta contrariar a afirmação de Todorov de que, na literatura fantástica, o leitor e o protagonista devem compartilhar do mesmo ponto de vista. Porém, essa hipótese é equivocada porque Stableford nunca tencionou escrever um conto de estranho puro em primeiro lugar. O que ele fez foi utilizar as convenções narrativas do estranho puro para subverter as expectativas do leitor lovecraftiano, o leitor-modelo do autor, a quem ele destina o texto e espera que decodifique o verdadeiro sentido da história narrada. Stableford, a grosso modo, disfarçou seu conto fantástico maravilhoso de 
estranho puro, e tal disfarce só foi possível porque o autor sabe a qual tipo de leitor sua narrativa se destina, o leitor lovecraftiano, aquele que verá através do disfarce, e Stableford espera que ele faça isso, e enxergue a verdade que está além da capacidade cognitiva e dos conhecimentos do protagonista David Stevenson.

Pode-se afirmar que Stableford realizou uma operação semelhante à de histórias policiais em "The Innsmouth Heritage". Em outras palavras, assim como em muitos contos policiais o leitor consegue deduzir quem é o assassino antes que o protagonista consiga e, dependendo da história, às vezes descobre quem é o assassino enquanto o protagonista chega ao final da narrativa sem jamais desvendar o mistério, ou mesmo levando à justiça um inocente. David Stevenson permanece alheio à verdade sobre Innsmouth, porém certo de que desvendou o mistério.

O clímax de "The Innsmouth Heritage" não está nas falsas descobertas do protagonista David Stevenson, mas no leitor lovecraftiano conhecer a verdade da qual o personagem está completamente alheio, tal qual o leitor-modelo do conto policial que percebe quem é o assassino verdadeiro que passou despercebido pelos olhos do detetive.

\section{CONCLUSÃO}

O subgênero do horror lovecraftiano, se por um lado tem sido um dos mais prolíficos, gerando incontáveis antologias e romances, por outro tem sido alvo de inúmeras críticas, sendo que a principal é que tais autores falham em reproduzir a estética literária de Lovecraft, resultando muitas vezes em trabalhos medíocres. S.T. Joshi, o maior especialista na obra de Lovecraft, comenta: 
Lovecraft has certainly left his mark on the work of Stephen King, Clive Barker, Whitley Strieber, and others, but much of this influence is sporadic and tangential. Perhaps this is as it should be: any writer who has something of his own to say will not stoop to blatant imitation, but will use another writer's work as springboard for self-expression [...] As for those writers who have nothing of their own to say and who find the pinnacle of achievement in copying someone else's vision or modes of expression, it would be merciful if they would simply shut up. (JOSHI, 1999, p.267-268)

Quanto a Stableford, é seguro afirmar que o autor escapou da armadilha de ser apenas um imitador barato de Lovecraft, ao seguir o caminho oposto do esperado pelo leitor lovecraftiano. Enquanto Lovecraft aposta no horror explícito e na confirmação do fantástico, Stableford utilizou-se de elementos do estranho puro para criar uma narrativa que, de certa forma, pode ser chamada de antilovecraftiana. Porém, tal termo não deve ser entendido literalmente, pois o horror lovecraftiano em "The Innsmouth Heritage" está justamente no fato de que o leitor-modelo sabe tudo a respeito dos horrores de Innsmouth, enquanto o protagonista chega ao final da narrativa desconhecendo os fatos. É nesse efeito de apreensão, nesse desejo do leitor-modelo poder dizer ao protagonista "Você está errado!" é que reside a presença do fantástico.

Stableford, portanto, foi hábil ao, no lugar de tentar imitar a estética fantástica de Lovecraft - o que o colocaria numa posição onde ele se arriscaria a ser visto como mais um imitador inferior -, optar por deixar o próprio Lovecraft realizar esta operação. Em outras palavras, Stableford, ao optar por narrar a história como uma espécie de pseudo- 
estranho puro, e dessa forma negar ao leitor-modelo a presença do fantástico, deixou que as informações do leitor-modelo acerca das histórias de Lovecraft identificassem o fantástico escondido por trás da camada de estranho puro.

Na passagem abaixo Brian Stableford, na introdução de seu The Innsmouth Heritage and Other Sequels (2009), ao comentar o seu processo criativo, demonstra que está ciente de sua intenção de subverter a obra de Lovecraft.

The difference between literary theft and literary borrowing is akin to that between benefical and injurous mutation, the observed ratio being not dissimilar to that pertaining to biological mutation. [...] The mutational process to which recycled ideas are routinely subject are many and varied, but its easy enough to identify some broad categories, the most important of which are extrapolation, inversion, perversion and subversion. [...] All the stories in this collection are extrapolation, that being inherent to the definition of a sequel, but al of them also feature a degree and perversion, and its is the degree and direction of these further adjustment that characterize me as a writer. (STABLEFORD, 2009, p.7-8)

É interessante a comparação de Stableford com mutações genéticas porque o seu conto é, tanto no aspecto do conteúdo quanto da forma, uma mutação. No âmbito do conteúdo a extrapolação está na introdução do DNA na narrativa descoberta científica que veio muitos anos depois da morte de Lovecraft - como explicação para a "aparência de Innsmouth", dando um caráter científico para o fenômeno, embora o protagonista David Stevenson não esteja ciente das implicações 
que tais mutações acarretam naqueles que as carregam, a saber, tornar-se uma monstruosidade submarina à medida que se envelhece. Por outro lado, no âmbito da forma pode-se dizer, usando a analogia de Stableford, que, ao introduzir elementos de estranho puro em "The Innsmouth Heritage", ele causou uma mutação no horror de Lovecraft, que é, via de regra, um fantástico maravilhoso, subvertendo-o.

Concluindo, escrever horror lovecraftiano é uma tarefa que, se por outro lado depende muito da colaboração e dos conhecimentos do leitor lovecraftiano, por outro tem nesse mesmo leitor um desafio a ser superado, pois se trata de um leitor cujo autor terá que se esforçar muito se deseja satisfazê-lo.

\section{REFERÊNCIAS}

BORGES, Jorge Luis (1985). "O Conto Policial". In: Cinco Visões Pessoais. Editora Universidade de Brasília: Brasília.

BRAGA, Guilherme da Silva (2014). "Iä! Cthulhu Fhtagn! A Ascensão de Lovecraft como Demiurgo". In: A Ascensão de Chtulhu. Editora Argonautas: Porto Alegre.

ECO, Umberto (1986). Lector in Fabula: A Cooperação Interpretativa dos Textos Narrativos. São Paulo: perspectiva, 1986.

JOSHI, Sunand Tryambak (1999). A Subtler Magik: The Writings and Philosophy of H.P. Lovecraft. New Jersey: Wildside Press.

LOVECRAFT, Howard Phillips (2013). "A Sombra em Innsmouth". In: O Mundo Fantástico de H.P. Lovecraft. Allan Moares (Trad.) Jundiaí: Clock Tower.

(2007). "A Coisa na Porta da Soleira". In: O Horror em Red Hook. Celso M. Parcionik (Trad.) São Paulo: Iluminuras.

STABLEFORD, Brian. "The Innsmouth Heritage". In: The Innsmouth Heritage and Other Sequels. New Jersey: Wildside Press, 2009.

(2009). "Introduction". In: The Innsmouth Heritage and Other Sequels. New Jersey: Wildside Press. 
STELLA, Paulo Rogério (2005). "Palavra”. In: BRAIT, Beth (Orgs.) Bakhtin Conceitos - Chave. Ed. Contexto.

TODOROV, Tzevetan (1975). Introdução a Literatura Fantástica. Editora Perspectiva. 